\title{
ANALISA RANCANG BANGUN SISTEM INFORMASI PENERIMAAN KAS TERHADAP TOKO SERBA GUNA MEBEL
}

\author{
Taufik Hidayatulloh ${ }^{1}$, Rifa Nurafifah Syabaniah ${ }^{2}$, Eva Marsusanti ${ }^{3}$, Lisnawati Dewi ${ }^{4}$, Dinar \\ Ismunandar 5 \\ 1,2,3,4,5 Universitas Bina Sarana Informatika (UBSI) \\ taufik.tho@bsi.ac.id, rifa.rrf@bsi.ac.id, eva.emr@bsi.ac.id, lisnawati@bsi.ac.id, dinar@bsi.ac.id
}

\begin{abstract}
ABSTRAK
Penelitian ini dilakukan dengan cara menganalisa tiga variabel, variabel penelitian ini terdiri dari tiga jenis variabel diantaranya; variabel independen (rancangan bangun sistem informasi), variabel dependen toko mebel) dan variabel moderator (penerimaan kas). Tujuan dari penelitian ini ingin mengetahui pengaruh dari rancangan rancang bangun sistem informasi penerimaan kas terhadap toko serba guna mebel kabupaten sukabumi. pembahasan penelitian di fokuskan kepada tiga variabel dan diolah dengan menggunakan aplikasi microsoft excel dan spss 20 dengan quesioner yang telah di bagikan kepada karyawan toko serba guna mebel. berdasarkan hasil analisa kuisioner didapat bahwa terdapat pengaruh rancangan rancang bangun sistem informasi penerimaan kas terhadap toko serba guna mebel kabupaten sukabumi ditinjau dari proses penerimaan kas yang di buat terhadap permasalahan yang terjadi pada toko serba guna mebel, dibuktikan dengan pengujian uji validitas menggunakan microsoft excel dengan hasil pearson correlation $>0,5$ dan uji reliabilitas $>0,6$ menggunakan spss 20. Harapan ke depan penelitian dilanjutkan ke arah analisa pengujian variabel dan implementasi program.
\end{abstract}

Kata kunci: Analisis Rancang Bangun Sistem Informasi, Penerimaan Kas dan Toko Mebel

\begin{abstract}
ABSTRAK
The research is conducted by analyzing three variables, the research variables consist of three types of variables including; Independent variables (draft information system builds), furniture store dependent variables) and variable moderators (cash receipts). The purpose of this study wanted to know the effect of designing the design of the cash acceptance information system to the convenience store of Sukabumi District furniture. Research discussion is focused on three variables and processed using Microsoft Excel applications and SPSS 20 with Quesioner that have been shared to the employees of furniture multipurpose store. Based on the analysis of the questionnaire was obtained that there is the influence of designing the design of the system of cash receipts to the convenience store of Sukabumi District Furniture reviewed from the cash acceptance process made to the problems that occur At a multipurpose furniture store, evidenced by the validity test test using Microsoft Excel with the Pearson correlation $>0.5$ and the reliability test $>0.6$ using SPSS 20. Future research hopes are continued towards variable testing analysis and program implementation.
\end{abstract}

Key words: Design analysis of information systems, cash receipts and furniture stores 
JURNAL SWABUMI, Vol.7 No.2 September 2019, pp.128 135

ISSN: 2355-990X

\section{1. Pendahuluan}

Penerimaan kas merupakan salah satu kegiatan perusahaan menerima aliran kas masuk selama periode keuangan tertentu. secara umum penerimaan kas yang diterima oleh perusahaan yaitu baik berupa uang tunai maupun surat-surat berharga yang mempunyai sifat dapat segera digunakan, yang berasal dari transaksi perusahaan maupun penjualan tunai, pelunasan piutang atau transaksi lainnya yang dapat menambah kas perusahaan.

Toko Serba Guna Mebel merupakan salah satu unit usaha yang bergerak di bidang penjualan mebel furniture yang beralamat di Jl. Pamuruyan No.233 Cibadak Kabupaten Sukabumi. toko serba guna mebel adalah salah satu perusahaan yang melakukan kegiatan penerimaan kas, berdasarkan hasil observasi dinyatakan terdapat beberapa permasalahan pada sistem pencatatan penerimaan kas yang masih membutuhkan waktu lama, sehingga sulit mendapatkan informasi secara cepat, penyimpanan data yang tidak tersusun rapi, pengarsipan dokumen yang mudah hilang atau rusak dan Memungkinkan banyak sebagian data seperti kwitansi penjualan dimanipulasi oleh orang yang tidak bertanggung jawab. alternatip pemecahan masalah yang dilakukan adalah dengan dibuat sebuah rancangan rancang bangun system informasi penerimaan kas pada toko serba guna mebel kota sukabumi.

Rancang bangun sistem informasi ini diharapkan dapat mengatasi permasalahan pada penerimaan kas di toko serba guna mebel kota sukabumi sehingga kedepannya dapat di implementasikan dalam bentuk penerapan aplikasi. sebelum penerapan aplikasi di terapkan maka dilakukan analisis rancangan terlebih dahulu dengan menganalisa seberapa besar pengaruh rancangan yang telah dibangun agar aplikasi yang diterapkan sesuai dengan kebutuhan.

Tujuan dari penelitian ini adalah menganalisis hasil rancang bangun sistem informasi penerimaan kas atas penjualan pada toko serba guna mebel kabupaten sukabumi, untuk mengetahui seberapa besar pengaruh dari rancangan yang telah di buat terhadap permasalahan yang terjadi pada toko serba guna mebel kota sukabumi.

Menurut John Mc Manama, dalam (Yansyah, 2012) Sistem adalah sebuah struktur konseptual yang tersusun dari fungsi-fungsi yang saling berhubungan yang bekerja sebagai suatu kesatuan organik untuk mencapai suatu hasil yang diinginkan secara efektif dan efesien.

Pengertian Sistem informasi adalah kumpulan atau susunan yang terdiri dari perangkat keras dan perangkat lunak serta tenaga pelaksananya yang bekerja dalam sebuah proses berurutan dan secara bersama-sama saling mendukung untuk menghasilkan suatu produk. (Nataniel Dengen, 2009).

Sistem informasi merupakan suatu sistem yang saling barkaitan dan berintegrasi satu sama lain dan bertujuan menyediakan informasi untuk mendukung operasi, manajemen dan fungsi pengambilan keputusan dalam suatu organisasi. (Abdullah, 2015).

Dari beberapa teori tersebut dapat disimpulkan bahwa sebuah system memiliki sifat yang saling berkaitan dan tersusun baik itu perankat keras maupun perangkat lunak dan memiliki tujuan yang sama untuk pengambilan keputusan.

\section{a. Pengertian Penerimaan Kas}

Kas adalah salah satu unsur aktiva yang paling penting karena merupakan alat pertukaran atau pembayaran yang siap dan bebas digunakan untuk membiayai kegiatan operasional perusahaan. Hampir setiap transaksi perusahaan dengan pihak luar menggunakan kas. Oleh karena itu, kas mempunyai sifat mudah (Maknunah, 2016)Penerimaan kas dapat dikatakan perolehan harta dalam bentuk kas yang diterima oleh perusahaan dari customer ketika membeli barang. Penerimaan kas ini akan digunakan perusahaan untuk melanjutkan kegiatan operasionalnya dalam membeli persediaan kembali sehingga perusahaan dapat memproduksi kembali barang yang dijual dan untuk membayar segala biaya-biaya yang harus dikeluarkan oleh perusahaan seperti biaya tenaga kerja, penyusutan, dan biaya tak terduga lainnya. Penerimaan kas dapat diperoleh dari penjualan barang atau jasa, penagihan piutang, maupun hal-hal yang dapat 
dijadikan kas oleh perusahaan seperti bangunan yang dapat disewakan kepada pihak lain. (Maknunah, 2016)

Menurut Mulyadi (2008) dalam (Pakadang, 2012) Sistem Informasi Akuntansi Penerimaan Kas adalah satu jaringan prosedur yang dibuat menurut pola yang terpadu untuk melaksanakan kegiatan penerimaan kas dari penjualan rutin dan tidak rutin berdasarkan ketentuan-ketentuan dari perusahaan yang bersangkutan.

Berdasarkan teori tersebut penerimaan kas merupakan suatu kegiatan yang sangat penting bagi operasional perusahaan.

\section{b. Pengertian Mebel}

Menurut Auliannisa \&amp; Hani'ah, (2017) dalam (Lisnawati Dewi, 2018) definisi mebel atau furniture adalah perabot yang diperlukan, berguna atau disukai, seperti barang atau benda yang dapat dipindahpindah, digunakan untuk melengkapi rumah, kantor dan sebagainya.

Toko serba guna mebel merupakan toko yang memiliki kegiatan operasional menjual

\section{f. Pengertian Uji Validitas dan Reliabilitas}

Uji validitas dapat dihitung dengan cara membandingkan nilai $r$ hitung (correlation item total correlation) dengan nilai $r$ tabel dengan ketentuan untuk degree of freedom $(d f)=n-k$ (Sugiyono, 2014:128), dimana $n$ adalah jumlah sampel dan $\mathrm{k}$ adalah jumlah variable independen. Bila $r$ hitung $>r$ tabel, berarti pernyataan tersebut dinyatakan valid. $R$ hitung $<r$ tabel, berarti pernyataan tersebut dinyatakan tidak valid. Sementara uji reliabilitas merujuk pada kemampuan suatu instrument untuk diuji kembali dengan memberikan hasil yang relative constant. Artinya suatu instrument dikatakan reliable jika instrument itu memberikan hasil yang relative sama jika diuji secara berulangulang. Pada studi ini, pengujian reliabilitas akan menggunakan koefisien alpha cronbach. (Siti Rahmatia Tambe, 2018)

Realibilitas instrument digunakan untuk melihat apakah alat ukur yang digunakan menunjukkan konsistensi dalam mengukur gejala yang sama. Nilai reabilitas suatu konstruk variabel dikatakan baik jika nilai Cronbach`s Alpha > 0,6 maka dinyatakan reliable. (Samosir, 2015)

Menurut Ardiansyah (2018) sebuah alat ukur dinyatakan reliabel jika nilai
Cronbach Alpha lebih besar dari 0,6 dan nilai Cronbach Alpha if item deleted lebih kecil dari nilai Cronbach.

\subsection{Penelitian Sebelumnya}

(Yuni Nuryanti 1), 2017) telah meneliti mengenai; sistem penerimaan kas yang diterapkan di Klinik Bersalin Devalisha tidak sesuai dengan kajian teori sistem penerimaan kas. hal tersebut terjadi karena hanya beberapa komponen sistem penerimaan kas yang sesuai dengan kajian teori, diantaranya meliputi fungsi, dokumen dan prosedur penerimaan kas. Kesesuaian tersebut memberikan dukungan terhadap aktivitas operasional penerimaan kas yang terjadi di Klinik Bersalin Devalisha. Sedangkan ketidaksesuaian dengan kajian teori terdapat dalam penerapan catatan akuntansi yang mengakibatkan semakin lamanya proses pencatatan akuntansi, dan aktivitas pengendalian internal yang mengakibatkan lemahnya pengendalian internal di Klinik Bersalin Devalisha terkait sistem penerimaan kas.

(Siti Rahmatia Tambe, 2018) Telah meneliti tentang Pengaruh sistem informasi akuntansi terhadap penerimaan pajak kendaraan bermotor dikantor samsat dan dinas pendapatan daerah kalibahi kabupaten Alor. Dengan hasil penelitian berikut;

a. Kepuasan pengguna SIA berpengaruh signifikan terhadap penerimaan PKB di kantor

SAMSAT dan DISPENDA Kalabahi Kabupaten Alor. Kepuasan pengguna SIA yang baik adalah bagaimana pengguna turut serta dalam pengawasan dan memiliki sistem, karena dukungan pengguna dalam implementasi sistem memiliki peranan dalam menunjang keberhasilan sistem informasi itu sendiri.

b. Penggunaan SIA tidak berpengaruh signifikan terhadap penerimaan PKB di kantor SAMSAT dan DISPENDA Kalabahi Kabupaten Alor. Dalam hal ini, penggunaan SIA memang penting dalam penerimaan PKB namun tidak secara langsung mempengaruhi penerimaan PKB dikarenakan pengguna bukan hanya semata-mata meggunakan setiap sistem yang ada, tetapi memahami secara jelas sistem 


mana yang digunakan dalam
menginput data yang dibutuhkan.
C. Dukungan manajemen puncak tidak
berpengaruh signifikan terhadap
penerimaan PKB. Dalam hal ini,
dukungan manajemen puncak penting
bagi penerimaan PKB namun tidak
secara langsung mempengaruhi
penerimaan PKB dikarenakan bukan
hanya dukungan lisan semata
melainkan dukungan langsung atau
turut serta dalam menggunakan sistem
yang ada; dan

d. Kepuasan pengguna SIA, penggunaan SIA dan dukungan manajemn puncak berpengaruh secara simultan terhadap penerimaan PKB. Hal ini berarti ketiga variabel independen tersebut merupakan faktor-faktor yang mempengaruhi penerimaan PKB. Dengan demikian seorang (individu) harus memiliki rasa puas dalam arti sistem yang ada telah bersifat akurat, mudah dan tepat dalam menggunakan sistem itu serta dukungan dan tindakan penuh dalam sebuah institusi untuk mewujudkan tujuan organisasi.

\section{Metode Penelitian}

Metodologi penelitian dilakukan dengan menggunakan metode analisis deskriptif, penelitian deskriptif menurut Makmunah (2016) yaitu suatu metode pembahasan permasalahan yang sifatnya menguraikan, menggambarkan, membandingkan dan menerangkan suatu data atau keadaan yang sedemikian rupa sehingga dapat ditarik kesimpulannya untuk mencapai tujuan yang diinginkan.

Berdasarkan metode yang digunakan diharapkan penelitian ini dapat menarik kesimpulan untuk mengetahui seberapa besar pengaruh variabel yang diteliti.

\subsection{Teknik Pengumpulan Data}

Teknik Pengumpulan data yang dilakukan dengan cara penyebaran angket kuesioner yang di sebarkan kepada karyawan toko serba guna mebel kota Sukabumi.

Jenis data yang diolah berdasarkan objek penelitian yaitu rancang bangun system informasi, toko serba guna mebel dan penerimaan kas, kemudian di jadikan variable penelitian. selanjutnya tiga variable data penelitian ini dibuat dan dijadikan instrument pertanyaan yang digunakan untuk menganalisa seberapa besar pengaruh rancangan terhadap permasalahan penerimaan kas pada toko serba guna mebel.

\subsection{Teknik Analisis}

Teknik Analisis yang dilakukan pada penelitian ini yaitu;

a. Menganalisa penelitian rancang bangun sistem informasi penerimaan kas atas penjualan pada toko serba guna mebel kabupaten sukabumi.

b. Mengambil landasan-landasan teori yang berhubungan dengan masalah yang diteliti.

c. Membandingkan kedua data tersebut.

d. Menganalisa hasil rancangan rancang bangun sistem informasi penerimaan kas atas penjualan pada toko serba guna mebel kabupaten sukabumi dengan melakukan uji validalitas data kuisioner.

e. Dari hasil penelitian ditarik kesimpulan dan diberikan saransaran.

1. Hasil dan Pembahasan

a. Variabel Penelitian

\section{1) Variabel Independen}

Variabel ini sering disebut variabel stimulus, prediktor, antecedent. dalam bahasa indonesia disebut sebagai variabel bebas. Variabel bebas merupakan variabel yang mempengaruhi atau yang menjadi sebab perubahannya atau timbulnya variabel dependen (terikat). Variabel ini biasa disebut juga variabel eksogen. (Ridha, 2017). Sedangkan variabel independen pada penelitian ini adalah rancang bangun sistem informasi.

Berikut adalah rancangan activity diagram rancang bangun system informasi toko serba guna mebel yang dianalisa.

\section{a. Activity diagram form data jurnal penerimaan kas}

Berikut adalah rancangan form Jurnal Penerimaan Kas yang dilakukan bagi bagian administrasi; 


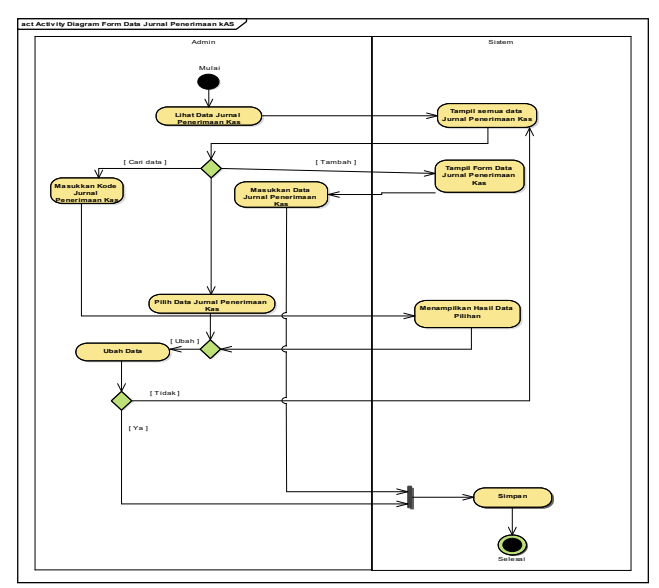

Gambar IV.1 Activity diagram form data jurnal penerimaan kas

Gambar diatas menjelaskan tentang rancang bangun sistem informasi tentang aktivitas rancangan jurnal penerimaan kas dengan aktor admin melihat data jurnal penerimaan kas yang ditampilkan di sistem, sistem akan menampilkan semua data jurnal penerimaan kas, selanjutnya maka akan ada instruksi masukan kode jurnal penerimaan kas, jika kode jurnal yang di masukan salah maka akan ada intruksi masukan kode jurnal penerimaan kas, tetapi jika kode benar maka diharuskan memilih data jurnal penerimaan kas. sistem akan menampilkan hasil data pilihan dan fasilitas untuk merubah data, jika data tidak di rubah maka admin diharuskan menyimpan data pada sistem.

\section{b. Activity diagram form laporan jurnal penerimaan kas}

Berikut adalah rancangan bagaimana cara mencetak laporan jurnal penerimaan kas yang dilakukan bagi bagian administrasi;

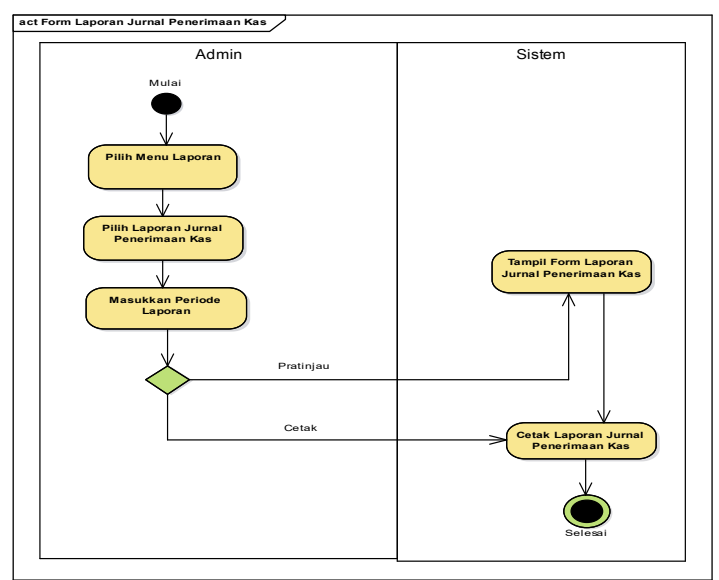

Gambar IV.2 Activity Diagram Form Data Laporan Jurnal Penerimaan Kas
Gambar ini menjelaskan tentang rancang bangun sistem informasi tentang aktivitas rancangan bagaimana admin mencetak laporan jurnal penerimaan kas dengan aktivitas admin memilih menu laporan pada sistem, memilih laporan jurnal kas penerimaan kas dan memasukan periode laporan, jika pilihan sesuai dan benar maka sistem akan menampilkan form laporan jurnal penerimaan kas kemudian sistem mencetak laporan jurnal penerimaan kas sesuai data yang telah di tampilkan sebelumnya. Jika tidak maka sistem akan mencetak laporan jurnal penerimaan kas data yang belum di rubah.

\section{e. Use Case Diagram}

Berikut adalah rancangan use case diagram rancang bangun sisyem informasi penerimaan kas pada toko serba guna mebel kota sukabumi;

Halaman Admin:

A1. Admin dapat mengelola data pelanggan

A2. Admin dapat mengelola data akun

A3. Admin dapat mengelola data barang

A4. Admin dapat mengelola data user

A5. Admin dapat mengelola data penjualan

A6. Admin dapat mengelola data pengiriman barang

A7. Admin dapat mengelola data jurnal penerimaan kas

A8. Admin dapat mengelola data laporan jurnal

A9. Admin dapat mengelola laporan penerimaan kas

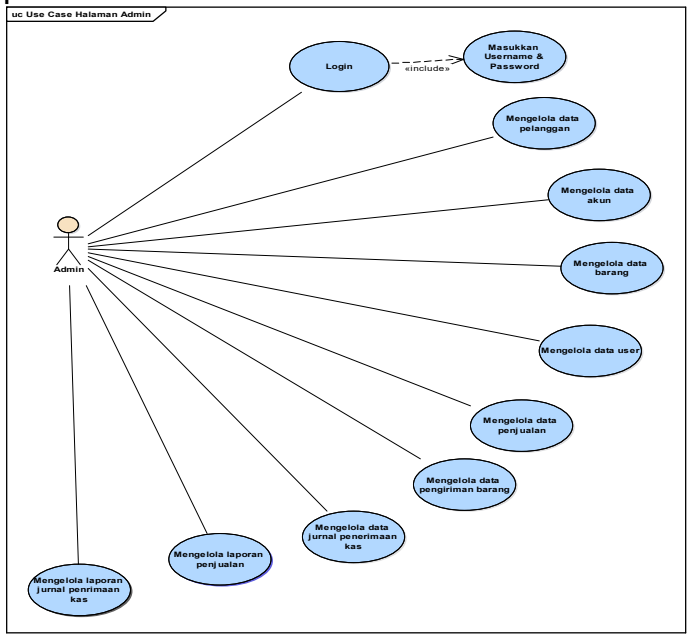

Gambar IV.3 Use Case Halaman Admin

Gambar ini menjelaskan tentang rancangan sistem informasi use case halaman admin, dimana admin dapat melakukan login dengan memasukan 
username dan password setelah login selsai maka akan tampil beberapa menu yang aktip diantaranya menu mengelola data pelanggan, mengelola data akun, mengelola data barang, mengelola data user, mengelola data penjualan, mengelola data pengiriman barang, mengelola data jurnal penerimaan kas, mengelola laporan penjualan dan mengelola laporan jurnal penerimaan kas.

\section{2) Variabel Dependen}

Variabel dependen disebut juga variabel output, kriteria, konsekuen. Dalam bahasa indonesia disebut variabel terikat. Variabel terikat merupakan variabel yang dipengaruhi atau yang menjadi akibat, karena adanya variabel bebas. Variabel terikat disebut juga varabel indogen. (Ridha, 2017). Variabel dependen pada penelitian ini adalah toko serba guna mebel.

Toko serba guna gebel adalah salah satu toko mebel yang berdiri sejak tahun 1992 yang berada di daerah Cibadak, beralamatkan di Jln. Pamuruyan No.233 Cibadak Sukabumi. toko serba guna mebel ini merupakan usaha dibidang perdagangan mebel atau perlatan rumah tangga seperti kursi, meja, tempat tidur dan lain-lain. toko serba guna mebel ini didirikan oleh Alm. Heriyanto bersama istrinya ibu Metty. sebelumnya usaha ini bernama toko guna mebel yang beralamatkan di nagrak, namun sejak awal tahun 2000 berubah nama menjadi toko serba guna mebel, sejak saat itu usaha ini dikelola oleh anaknya yaitu Bapak Budiyanto. usaha mebel ini sudah sangat luas pemasarannya hingga sampai ke pelosok-pelosok kampung yang ada di daerah Sukabumi.

\section{3) Variabel Moderator}

Variabel Moderator adalah variabel yang mempengaruhi (memperkuat atau memperlemah) hubungan antara variabel independen dengan dependen. (Ridha, 2017). variabel moderator pada penelitian ini adalah penerimaan kas.

Secara umum prosedur sistem penerimaan kas atas penjualan yang sedang berjalan di toko serba guna mebel meliputi prosedur:

a. Prosedur Penjualan

Pelanggan datang langsung ke toko dan memilih barang apa saja yang dibutuhkan oleh pelanggan tersebut. Jika pelanggan ingin membutuhkan barang namun stok di toko belum ada bisa memesan untuk beberapa hari atau memesan barang yang diinginkan oleh pelanggan tersebut.

b. Prosedur Penerimaan Pembayaran

Pelanggan yang sudah memilih barang dan sudah pasti membeli barang terseebut dipersilahkan untuk membayar uang secara tunai atau cash kepada bagian admin keuangan, karena di toko serba guna belum menyediakan pembayaran secara transfer via ATM. Kemudian bagian admin menerima uang yang diberikan oleh pelanggan tersebut. Kemudian admin keuangan membuat kwitansi dua rangkap. Kwitansi rangkap pertama akan dijadikan arsip dan rangkap kwitansi kedua akan diberikan kepada pelanggan sebagai bukti bahwa pelanggan telah selesai melakukan pembayaran.

c. Prosedur Pengiriman / Pengantaran Setelah proses pembayaran oleh pelanggan ke bagian admin, kemudian bagian admin membuat surat jalan dan menyerahkan surat jalan tersebut ke supir yang akan mengantarkan barang menggunakan mobil box. Jika barang diantar jauh pelanggan akan terkena biaya tambahan sebesar Rp. 20.000,-00.

d. Prosedur Pembuatan Laporan

Bagian administrasi membuat laporan penjualan barang berdasarkan transaksi beserta bukti transaksi dan diserahkan kepada pemilik toko, setelah diperiksa dan disetujui dan ditanda tangani oleh pemilik toko dan diarsipkan oleh pemilik toko.

\subsection{Hasil Pengujian}

1) Uji validitas

Uji Validitas digunakan untuk mengukur sah atau valid tidaknya suatu kuesioner. Suatu kuesioner dikatakan valid jika pertanyaan pada kuesioner mampu untuk mengungkapkan sesuatu yang akan diukur. Sebuah item pertanyaan dikatakan valid jika nilai korelasinya lebih besar dari nilai korelasi tabel pada tingkat signifikan $5 \%$ (Astuti, (2015).

a) Hipotesa $\mathrm{HO}$ : skor butir/item tidak berkorelasi positif dengan skor faktor b) Hipotesa H1: skor butir/item berkorelasi positif dengan skor faktor.

Dasar pengambilan keputusan:

a)Terima HO bila nilai Pearson Correlation $>$ 0,5 dan nilai sig.(2-tailed) $>0,05$ 
134

b)Tolak $\mathrm{HO}$ bila nilai Pearson Correlation < 0,5 dan nilai sig.(2-tailed) $<0,05$

Pada penelitian ini, peneliti mengumpulkan data dengan penyebaran kuesioner kepada Karyawan Toko Serba Guna Mebel Kota Sukabumi yang telah bekerja sebanyak 10 responden dengan memberikan 12 butir pertanyaan. Pengolahan data dilakukan dengan menggunakan Microsoft Excel.

\subsection{Uji Validitas Microsoft Excel;}

\begin{tabular}{|c|c|}
\hline Variabel & Person Corelation \\
\hline \multicolumn{2}{|c|}{ Rancang bangun sistem informasi. } \\
\hline $\mathrm{X} 1$ & 0.65 \\
\hline $\mathrm{X} 2$ & 0.71 \\
\hline X3 & 0.56 \\
\hline $\mathrm{X} 4$ & 0.53 \\
\hline \multicolumn{2}{|c|}{ Penerimaan kas } \\
\hline $\mathrm{X} 5$ & 0.59 \\
\hline $\mathrm{X6}$ & 0.69 \\
\hline $\mathrm{X7}$ & 0.58 \\
\hline $\mathrm{X} 8$ & 0.91 \\
\hline \multicolumn{2}{|c|}{ Toko serba mebel } \\
\hline $\mathrm{X9}$ & 0.63 \\
\hline $\mathrm{X} 10$ & 0.55 \\
\hline $\mathrm{X} 11$ & 0.81 \\
\hline $\mathrm{X} 12$ & 0.52 \\
\hline
\end{tabular}

Analisa uji validitas, diketahui bahwa nilai Pearson Correlation $>0,50$ dan nilai Sig. (2-tailed) dibawah nilai signifikansi $(0,05)$ untuk seluruh variabel penelitian, sehingga pertanyaan dalam kuesioner dianggap layak untuk mengukur variablevariabel yang ingin diketahui oleh peneliti.

2) Uji Reliabilitas

Uji reliabilitas hanya dapat dilakukan setelah suatu instrumen telah dipastikan validitasnya. Pengujian reliabilitas dalam penelitian ini untuk menunjukan tingkat reliabilitas konsistensi setiap instrumen yang digunakan adalah dengan mengukur koefisien Cronbach's Alpha dengan bantuan program SPSS 20. menurut Ardiansyah (2018) sebuah alat ukur dinyatakan reliabel jika nilai Cronbach Alpha lebih besar dari 0,6 dan nilai Cronbach Alpha if item deleted lebih kecil dari nilai Cronbach.

Tabel 4.2 Uji Reliabilitas SPSS 20

\begin{tabular}{|l|l|l|}
\hline Variabel & $\begin{array}{l}\text { Cronboch } \\
\text { Alfa }\end{array}$ & Hasil \\
\hline $\begin{array}{l}\text { Rancangan } \\
\text { bangun } \\
\text { sistem } \\
\text { informasi }\end{array}$ & 0,61 & Reliabel \\
\hline $\begin{array}{l}\text { Penerimaan } \\
\text { kas }\end{array}$ & 0,59 & Reliabel \\
\hline $\begin{array}{l}\text { Toko Serba } \\
\text { Mebel }\end{array}$ & 0,62 & Reliabel \\
\hline
\end{tabular}

Berdasarkan hasil uji reliabilitas menyatakan bahwa seluruh variabel dinyatakan reliabel karena memiliki nilai cronbach alpha> 0,6. Berikut hasil uji reliabilitas:

\section{Kesimpulan}

\subsection{Simpulan}

Berdasarkan hasil analisis rancang bangun sistem informasi penerimaan kas terhadap toko serba guna mebel, maka dapat ditarik kesimpulan sebagai berikut:

a. Variabel penelitan yang diujikan pada penelitian ini dianggap layak untuk mengukur variable-variabel yang ingin diketahui yaitu variabel independen (Rancang Bangun Sistem Informasi), variabel dependen (Toko Serba Guna Mebel) dan variabel moderator (Penerimaan Kas) dibuktikan dengan pengujian uji validitas menggunakan Microsoft Excel dengan hasil Pearson Correlation $>0,5$ dan uji reliabiltas $>0,6$.

b. Terdapat pengaruh yang valid dari rancangan yang telah di rancang terhadap permasalahan yang di temukan pada toko serba guna mebel kota sukabumi dan harus dilanjutkan ke tahap implementasi aplikasi.

\subsection{Saran}

Penelitian ini masih harus dilanjutkan ke tahap implementasi program aplikasi yang telah di rancang kemudian di analisa kembali sehingga permasalahan yang terjadi di toko serba guna mebel benarbenar bisa diatasi.

2. Daftar Rujukan

Abdullah, D. (2015). Perancangan Sistem Informasi Pendataan Siswa SMP Islam Swasta Darul Yatama Berbasis Web . IJNS - Indonesian Journal on Networking and Security , 39-44. 
Asep Saepul Hamdi, E. B. (2014). Metode Penelitian Kuantitatif Aplikasi dalam Pendidikan. In E. B. Asep Saepul Hamdi, Metode Penelitian Kuantitatif Aplikasi dalam Pendidikan (p. 5). Yogyakarta: CV Budi Utama.

Astuti, Y. K. ( (2015)). Financial Stressors, Financial Behavior, Risk Tolerance, Financial Solvency, Financial Knowledge, dan Kepuasan Finansial. FINESTA Vol. 3, No. 1, 19-23.

Ardiansyah, I. (2018). PENGARUH KUALITAS WEBSITE TRAVELOKA TERHADAPKEPUASAN KONSUMEN DENGAN MENGGUNAKAN METODEWEBQUAL. Sustainable Tourism Industry for Economic Development , 351366.

Doro Edi, S. B. (2009). Analisis Data dengan Menggunakan ERD dan Model Konseptual Data Warehouse . Jurnal Informatika, Vol.5, No. 1, 71-85.

Dr. Farida Nugrahani, M. (n.d.). MNetode Penelitian.

Lisnawati Dewi, D. I. (2018). Rancang Bangun Sistem Informasi Penerimaan Kas pada toko serba guna mebel. Sukabumi: Amik Bsi .

Maknunah, J. (2016). ANALISIS SISTEM INFORMASI AKUNTANSI

PENERIMAAN DAN

PENGELUARAN KAS PADA LEMBAGA PENDIDIKAN . SMATIKA Jurnal Volume 06, 27-39.

Nataniel Dengen, H. R. (2009).

Perancangan Sistem Informasi

Terpadu Pemerintah Daerah

Kabupaten Paser. Jurnal Informatika Mulawarman, 47-54.

Pakadang, D. (2012). EVALUASI

PENERAPAN SISTEM

PENGENDALIAN INTERN

PENERIMAAN KAS PADA RUMAH

SAKIT GUNUNG MARIA DI

TOMOHON. Jurnal EMBA: Jurnal

Riset Ekonomi, Manajemen, Bisnis dan Akuntansi , 213-223.

Ridha, N. (2017). PROSES PENELITIAN, MASALAH, VARIABEL DAN PARADIGMA PENELITIAN . Jurnal Hikmah, 62-70.

Samosir, C. B. (2015). JURNAL

PENGARUH PERSEPSI HARGA DAN
PROMOSI TERHADAP KEPUTUSAN

PEMBELIAN KONSUMEN PRODUK

ENERVON-C. Jurnal IImiah Manajemen

dan Bisnis , 2-13.

Siti Rahmatia Tambe, H. S. (2018)).

PENGARUH SISTEM INFORMASI

AKUNTANSI TERHADAP

PENERIMAAN PAJAK

KENDARAAN BERMOTOR DI

KANTOR SAMSAT DAN DINAS

PENDAPATAN DAERAH

KALABAHI KABUPATEN ALOR. JURNAL AKUNTANSI (JA), 60-78.

Yansyah, A. (2012). ANALISIS

PERANCANGAN SISTEM

INFORMASI KEPEGAWAIAN

PADA KANTOR UNIT

PELAKSANA TEKNIS DINAS

PENDIDIKAN KECAMATAN

GUNUNG ALIP KABUPATEN

TANGGAMUS BERBASIS

WEBSITE. Konferensi Mahasiswa

Sistem Informasi, 1-6.

Yuni Nuryanti 1), S. S. (2017). EVALUASI

SISTEM INFORMASI AKUNTANSI

PENERIMAAN KAS STUDI KASUS

PADA KLINIK BERSALIN

DEVALISHA. Jurnal Penelitian dan

Kajian IImiah Fakultas Ekonomi

Universitas Surakarta, 72-80. 
